\title{
Flipped Classroom for Finance Students: Participative Learning and Flexible Assessment
}

\author{
Sheeba Kapil \\ Department of Finance, Indian Institute of Foreign Trade, New Delhi, India \\ Email: sheebakapil@iift.edu
}

How to cite this paper: Kapil, S. (2019) Flipped Classroom for Finance Students: Participative Learning and Flexible Assessment. Theoretical Economics Letters, 9, 2771-2784.

https://doi.org/10.4236/tel.2019.98174

Received: October 31, 2019

Accepted: November 29, 2019

Published: December 2, 2019

Copyright $\odot 2019$ by author(s) and Scientific Research Publishing Inc. This work is licensed under the Creative Commons Attribution International License (CC BY 4.0).

http://creativecommons.org/licenses/by/4.0/

(c) (i) Open Access

\begin{abstract}
Flipped classrooms are all about flexible teaching and learning in higher education and require flexible assessment components along with flexible teaching. The study aimed at understanding the effect of student interaction, engagement in flipped classroom on student knowledge, skill and attitude towards the subject finance, topic business valuation. Accounting and finance subjects require a sharp focus on pedagogy and learning approaches. Finance is a core fundamental subject in higher education like MBA that creates base for further advance learning and knowledge application. A pre-test and post-test design were carried out with sample t-test and linear regression model. The study created two groups flipped and non-flipped classroom using 2 E-learning cycles in a Finance class of MBA first trimester students. The result showed that learning was better in flipped classroom. The student satisfaction level was also better. Both classrooms showed good learning with active learning approach and active instructor participation. Outside the classroom students shared that had engaging experience with teaching as well as flexible assessment through more choices and preferences. The limiting factor was that flipped classroom teaching lacked institution support and confidence. Both flipped classroom and flexible evaluation are missing from curriculum design and evaluation process. The aim of this paper was to provide quantitative and controlled data about the effectiveness of flipped classroom learning.
\end{abstract}

\section{Keywords}

Flipped Classroom, Valuation, Flipped Learning, Excel Spreadsheet, Participative Learning, Flexible Assessment

\section{Introduction}

The technological advents in teaching methods have impacted learning and have 
created scope for low as well as deep rooted learning from active instructors through offline mode like flipped classroom (Arnold, I. [1]). Increasingly students have taken to online courses and contents to facilitate their knowledge and learning of concepts that were considered too technical to be learned outside the classroom. Finance and Accounting is one subject where technicalities and skill learning have traditionally been feasible only in classroom mode (Adler, R.W. and M. J. Milne [2]). Flipped classroom provides space for students learning as a part of individual learning space, with the help of one of several technologies. (Hamdan et al. [3]). The main idea is to facilitate learning through instructional videos, recorded lectures, and self-assessment evaluations (Cynthia, R. and E. Joseph [4]). Post self-learning phase the instructor then spends in-class time applying the finance concept through problem solving excel based spreadsheet exercises, and peer interaction (Strayer [5]; Tucker [6]; Gajjar [7]; Sarawagi [8]). (Sarawagi [8]) suggests that it is defined by facilitating low-level (terms, definitions, and basic content) learning outside class and high-level (application-based) learning within the class (Mayer, R. E. [9]).

According to the constructivist, inquiry-based, learning cycle model (Heiss et al. [10]; Bybee [11]; Lawson [12] ), teaching consists of two phases: a phase in which students are gaining conceptual understanding (hereafter referred to as the content attainment phase) and a phase in which students learn to apply and/or evaluate those concepts in novel situations in order to broaden their conceptual understanding beyond the context in which they learned it (hereafter referred to the concept application phase).

Traditional teaching methods facilitate content attainment through various means in a classroom setting and direct instructor and student interface (Leicht, R. M., S. E. Zappe, J. I. Messner, T. Litzinger and P. State [13]). Later students are then given the responsibility of applying the concepts, generally in the form of quiz, homework assignments and end term. In flipped classroom instructor facilitation is extremely important as outside classroom learning can be conducted effectively only through efficient learning approaches (Vygotsky [14]). Research has also been done on the complete presence or absence of an instructor, comparing entirely online courses with face-to-face courses (Missildine, K., R. Fountain, L. Summers and K. Gosselin [15]). Results are mixed and confounded by the many different variables involved, that is, active versus passive approaches, inclusion of blended models, and differences in instructional material and learning time; (see Means et al. [16]), for a meta-analysis. From this, it seems that an instructor can play an important role; however, a theoretical rationale for the differential importance of the instructor in each phase of learning is impossible to establish (Clark, R. M., B. A. Norman and M. Besterfield-Sacre [17]).

Studies testing the effectiveness of the flipped model currently consist of either case studies, in which practitioners describe the implementation of a flipped model in their own classroom and report primarily affective data (e.g., Lage et al. [18]; Bergstrom [19]; Fulton [20]; Johnson [21]), or comparison studies, in which the flipped model is compared directly with traditional didactic methods 
(e.g., Strayer [5]; Tucker [6]; Tune et al. [22]). Comparative studies can offer different insight in a more generalizable manner; researchers are finding positive trends in a flipped environment over a traditional environment (Bergstrom [23]; Strayer [5]; Tucker [6]; Tune et al. [22]). Bergstrom [23] compared a passive lecture model with an approach that used online content delivery. Bergstrom found more positive opinions from students utilizing online content, although exam scores showed no differences. In 2012, Strayer ran a statistics course in both lecture-based and active flipped formats. Student attitudes and impressions showed slight improvement in the flipped condition; no quantitative learning gains were measured (Kazu, I. Y. and M. Demirkol [24]). Tucker [6] suggests that, in high school settings, the flipped model leads to better relationships between students and the instructor, greater student engagement, and higher motivation (Keller, J. M [25]). McLaughlin et al. [26] flipped an introductory pharmaceutics course at a pharmacy school and found that student attitudes and self-reported learning were greater in the flipped model (Siegle, D [27]).

The goal of this study was to take the first step into providing such quantitative and controlled data about the effectiveness of the flipped model. Specifically, we aimed to compare a flipped model with a nonflipped model while only varying the role of the instructor, thus controlling for as many of the other potentially influential variables as possible, especially the influence of active learning (Kim, M.K., S.M. Kim, O. Khera and J. Getman [28]). A 5-E learning cycle model (Bybee [11]) was used in both treatments. In the nonflipped model, the instructor's responsibility lay within the content attainment process, while the responsibility of concept application was delegated to the student as homework assignments, quizzes, and other assessments (albeit, often utilizing peer interactions) (Siti, Z. M. O., J. Rozinah and E. M. Nur [29]). Alternatively, in the flipped model, the student was given responsibility for content attainment before class, and the instructor was then able to facilitate concept application through complex problem-solving and group work on items that would traditionally have been homework assignments (Ryan, R. M. and E. L. Deci [30]). It would seem logical that instructor and peer facilitation are equally important in both phases; however, classroom time constraints necessitate the delegation of one of the phases to students. If it matters where instructor and peer facilitation take place, we predicted that we would see a clear difference in treatment conditions between a non-flipped learning cycle and a flipped learning cycle model (Flumerfelt, S. and G. Green [31]). Currently this comparison has not been made; it was therefore impossible to make a research-driven prediction on which condition would be superior.

\section{The MBA Program}

The MBA program at Indian Institute of Foreign trade New Delhi, India a deemed university is the flagship program that creates future leaders. It is one of the top business school in the country and is under the ministry of commerce 
India. The MBA curriculum was recently revised and is now organized into basic core courses, and electives. Each student takes 15 electives of 2 credit (20 hrs) each over fourth, fifth and sixth trimester. Finance is basic core course that creates foundation for elective courses in finance. The finance course facilitates students' decision-making ability and the use of computer technology and excel based spreadsheet exercises (Davies, R.S., D.L. Dean and N. Ball [32]) and simulation to support management-science modelling and problem-solving activities. All students have personal laptop (Gagne, R., L. Briggs and W. Wager [33]). IIFT also has its own computer labs connected to a local area network (LAN), the Internet, and use financial databases both within classrooms and outside classrooms (Pierce, R. and J. Fox [34]).

\section{Research Methodology}

Design of the Study

The study adopted a mixed method analysis using both quantitative and qualitative methods (Creswell [35]). This study used quantitative student pre- and post-test achievement data, a questionnaire on student interaction, student engagement, satisfaction and their knowledge, skills, and abilities (KSAs) and structured questions of overall student perception on flipped classrooms (Murray, D., T. Koziniec and T. Mcgill [36]). A flipped classroom course that covered topics like business valuation was designed and developed. The independent variable of the study was the flipped classroom course, student interaction and student engagement; the dependent variables were the satisfaction, KSAs and post-test achievement toward the topic. The Sample size comprises of $160 \mathrm{stu}-$ dents taking the core finance course.

The Flipped Classroom Course: The business valuation topic was designed and developed as a flipped classroom course for the purpose of this study. Business valuation requires basic accounting and finance understanding and facilitates decision making of the future managers. The flipped classroom course adopted two phased approaches. The first phase included outside classroom learning of around 2 hrs per week and second phase required 2 hrs per week. The flipped classroom ensured that each student had his/her personal laptop during the period. Video lectures, lesson plan with objectives and outcome along with other learning material and excel based exercises were designed and uploaded on learning platform of IIFT developed in-house called campus 360 with address campus360.iift.ac.in. learning platform of IIFT has components of resources wherein resources are uploaded by faculty and online student attendance, assignment sets, feedback can be managed. The learning platform campus360.iift.ac.in, included content presentation structure of the learning material supported with active learning activities as planned Jonassen [37]. The procedure of flipped classroom was using FLIPPED model by Chen et al. [38] It aimed to help lecturers and students to flip and were not allowed to miss and avoid (Figures 1-3, Table 1). 


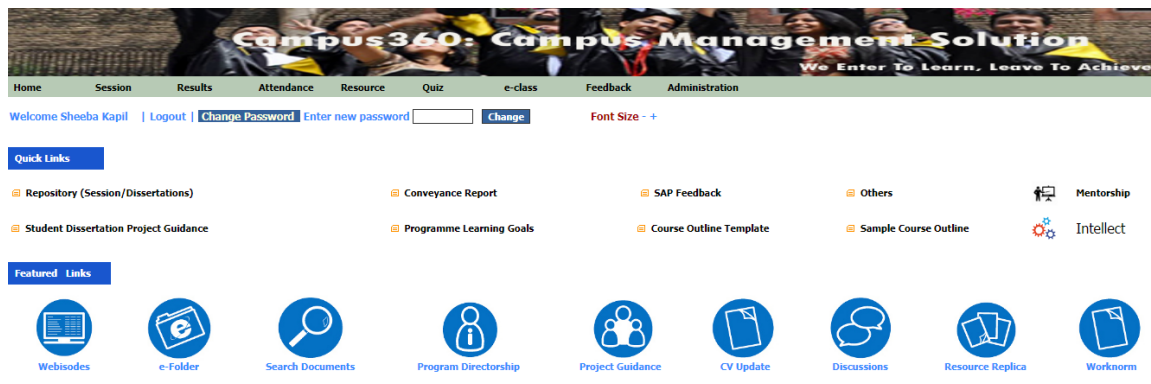

Figure 1. The learning platform: campus360 of IIFT, India. Source: http://campus360.iift.ac.in/mainmore.asp.

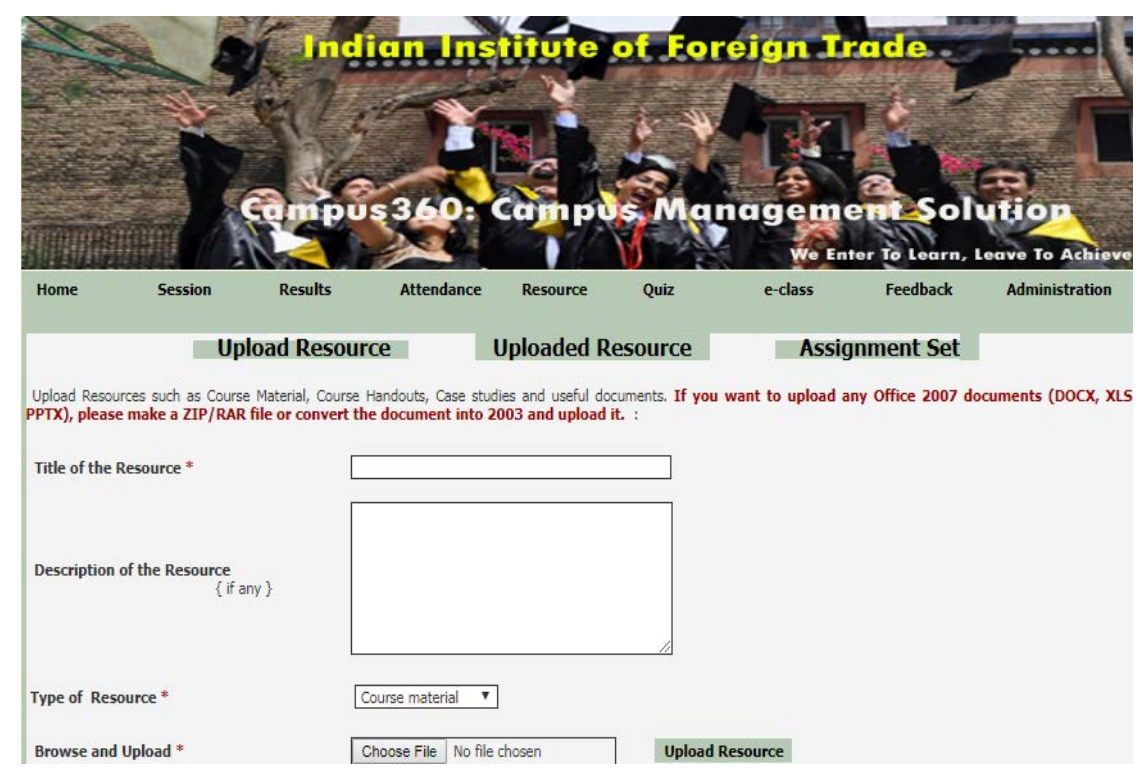

Figure 2. The learning platform: Resources, assignment and other flipped classroom material uploads and access on campus360 of IIFT, India. Source: http://campus360.iift.ac.in/mainmore.asp.

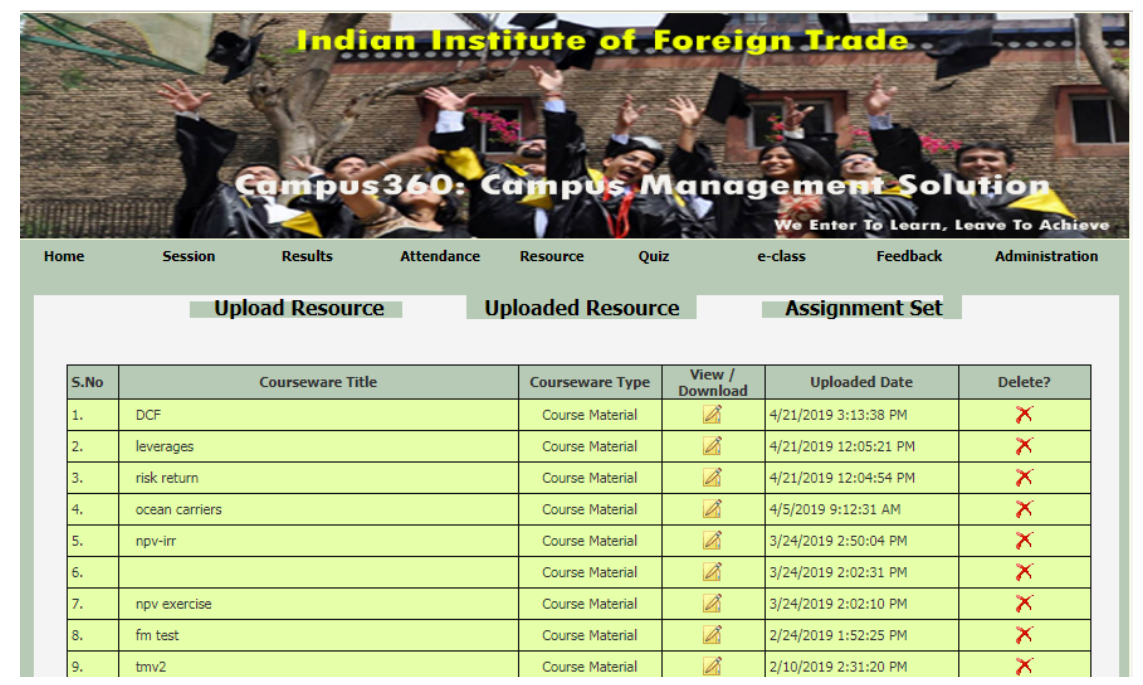

Figure 3. The learning platform: Uploaded resources sharing platform on campus360 of IIFT, India. Source: http://campus360.iift.ac.in/mainmore.asp. 
Table 1. FLIPPED model learning process.

\begin{tabular}{|c|c|c|}
\hline Model & Learning process & Instruction/material \\
\hline $\mathrm{F}$ & $\begin{array}{l}\text { Students enrolled for flipped classroom take up survey } \\
\text { for need assessment }\end{array}$ & Campus360/survey \\
\hline $\mathrm{L}$ & $\begin{array}{l}\text { Students enrolled will have access to resources like } \\
\text { video lectures outside classroom followed by full } \\
\text { participation in class with lecturer and peers, } \\
\text { completing assignment and tutorial. Both learning } \\
\text { environment will include active learning activities. }\end{array}$ & $\begin{array}{l}\text { Campus360/Pre-class } \\
\text { assignment/tutorial } \\
\text { exercise and excel exercises }\end{array}$ \\
\hline I & $\begin{array}{l}\text { Interaction outside classroom facilitated, } \\
\text { between student-material, student-student and } \\
\text { student-lecturer enabling student to explore and } \\
\text { use the knowledge to engage in class activities. }\end{array}$ & $\begin{array}{l}\text { Campus } 360 \text { discussion } \\
\text { board/tutorial exercise and } \\
\text { excel exercises }\end{array}$ \\
\hline $\mathrm{P}$ & $\begin{array}{l}\text { Instructor facilitates the discussion board } \\
\text { and use of in class time. }\end{array}$ & $\begin{array}{l}\text { Campus } 360 \text { discussion } \\
\text { board/tutorial exercise } \\
\text { and workbook }\end{array}$ \\
\hline $\mathrm{P}$ & $\begin{array}{l}\text { Instructor uses Campus } 360 \text { which was free, easy and } \\
\text { user friendly for student to sign-up and log in and } \\
\text { still have face to face time as traditional classroom. }\end{array}$ & $\begin{array}{l}\text { Campus360/tutorial } \\
\text { exercise and workbook }\end{array}$ \\
\hline $\mathrm{E}$ & $\begin{array}{l}\text { Based on student interaction on Campus } 360 \text { and } \\
\text { pre-class assignment, lecturer will take } \\
\text { consideration which part need to be emphasized } \\
\text { to engage student with in-class activities. }\end{array}$ & $\begin{array}{l}\text { Campus360discussion } \\
\text { board/tutorial exercise } \\
\text { and workbook }\end{array}$ \\
\hline $\mathrm{D}$ & $\begin{array}{l}\text { Instructor creates video lecture etc that student } \\
\text { need to watch and practice with workbook provided } \\
\text { and play an active role in the learning platform to } \\
\text { create student interaction and pre-class assignment } \\
\text { for active learning activities outside classroom. }\end{array}$ & $\begin{array}{l}\text { Campus } 360 / \text { tutorial notes, } \\
\text { videos, exercise and } \\
\text { excel workbook }\end{array}$ \\
\hline
\end{tabular}

\section{Data Collection Instruments}

The study used an achievement test and questionnaire to collect relevant data. The achievement test on business valuation topic was designed both as pre-test and post-test. The achievement test was designed in the beginning of the trimester and was applied to both flipped and non-flipped students Pre-test enabled the study to understand the students' prior knowledge on the topic. Post-test enabled the study to understand students' knowledge acquisition on the course content (Wilson, S.G [39]). The achievement test comprised of small applied case study with requisite data to conduct business valuation. The item of measuring students ${ }^{\text {ee }}$ satisfaction was adopted from Roach [40], student interaction, student engagement and KSAs were adapted from Kuo et al. [41]; Reeve [42] and Adler and Milne [2] had 55 five point-likert types. The items were all coded from 5 (strongly agree) to 1 (strongly disagree), expect for KSAs item which were coded from 1 (to no extent) to 5 (to great extent) for each statement. The alpha reliability coefficient of the questionnaire scale was .87 thus indicating overall reliability of the instrument.

\section{Conducting the Study}

Flipped classroom activities start with online registration of students on cam- 
pus360, the learning platform of IIFT (see Figure 4). Individual login ids are created and are not linked to any social media to avoid any conflict and time wastage. Students can download the business valuation content, lesson plan, course structure with pedagogy, and online test. Business valuation topic needs to be studied by students enrolled in flipped classroom 2 weeks before class meeting. The survey questions are filled by students as they log in flipped classroom and then they proceed with downloads and course content. A continuous feedback is taken from students in from of mid-term feedback and end term feedback (Crews, T. and J.B. Butterfield [43]). The students need to actively engage in class with peers and the instructor. Each online tutorial materials are viewed and then summarized by students online to ensure active engagement. pre-classroom assignments are given to ensure flipped classroom learning.

On completion of two weeks and assigned activities during the period, the in-class activities start. Test 2 is conduced as pre-test before the session starts. Flipped classroom on business valuation topic consist of $2 \mathrm{hr}$ class every weak. Common content is covered for all classes and the lessons lasted for 10 weeks. Half an hour is devoted to student problems on outside classroom activities and pre-class assignment they must complete. Separate query solving platform is also initiated on campus 360 for discussion. The student then engaged with classroom activities with problem solving exercises and tutorials with group and individual activities, questions-answers about the problem and preparing the business valuation report of the case provided to them. With the guidance of the instructor the discussion is directed to engage the students. Subsequently students engage on oncampus360 discussion and resource board for next lesson. On completing $10^{\text {th }}$ week, students will take same "Test 2 " as a post-test and answer the questionnaire. The data collected through the pre-and post-test and questionnaire were analysed through paired sample t-test and linear regression analysis using SPSS.

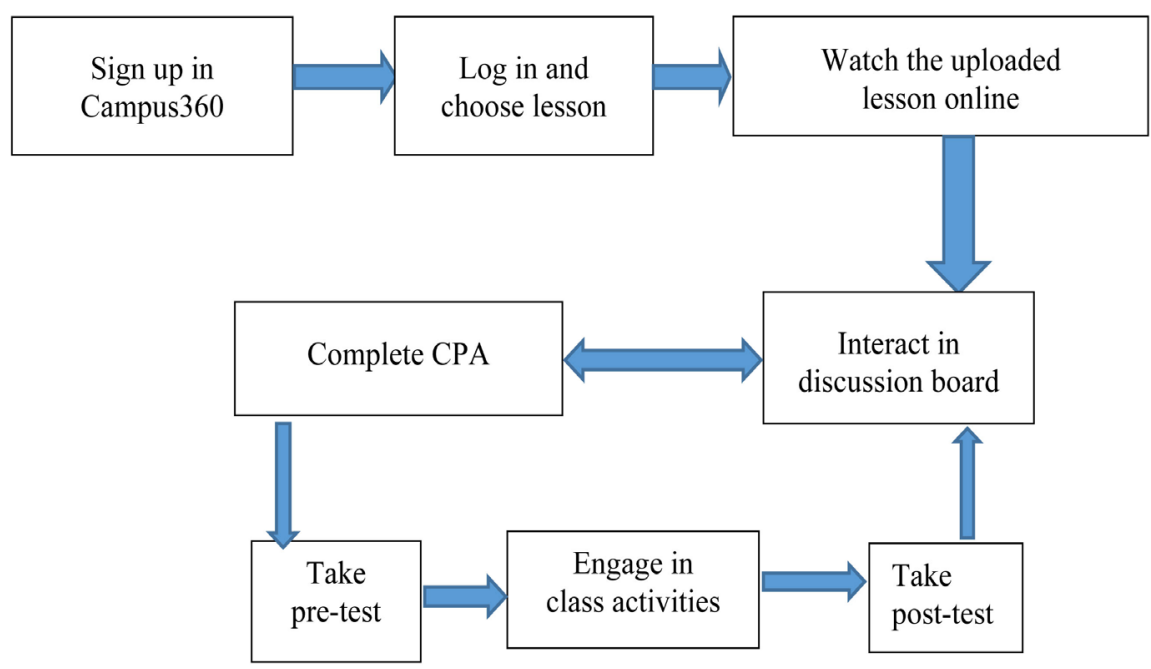

Figure 4. Activities in the business valuation flipped classroom. 


\section{Results and Discussion}

The data collected through the pre-and post-test and questionnaire were analysed through descriptive and inferential statistics such as paired sample t-test and linear regression analysis using SPSS. The results were examined accordingly with the study's research questions.

\subsection{Difference between Pre-Test and Post-Test Achievement in Flipped Classroom Environment}

Regarding the first question of the study, Table 2 shows the results of the paired sample t-test performed in order to find the significance of the difference between pre-test and post-test mean scores in flipped classroom environment.

It was found out that the flipped classroom approach on business valuation topic led to a significant increase in student achievement scores $(t(55)=-3.14$, $\mathrm{p}$ < 0.05). The mean score of student achievement increased from 69.72 to 77.36. These findings show student interaction outside classroom and student engagement inside classroom in flipped classroom environment on business valuation topics have an important effect on the design and development using FLIPPED model related to student satisfaction and their knowledge, skills, and abilities (KSAs). As a result of $\mathrm{SD}=28.64$, students had a significantly higher achievement when implementing the flipped classroom compared to before the lesson started.

\subsection{Difference between the Effect of Student Interaction on Student Satisfaction, Students KSAs and Student Achievement in Flipped Classroom Environment}

The correlation between student interaction and student achievement is very low with the $\mathrm{R}=0.170$, and the effect on student achievement only $2.8 \%$ explained by student interaction, which is very small variation (Table 3 ). However, compared with student satisfaction and student KSAs, where the $\mathrm{R}=0.788 ; 0.692$ which indicate high correlation between student interaction and student satisfaction and average correlation with student KSAs. In addition, with student interaction there is a large variation of effect on student satisfaction with $62.1 \%$ and only $47.8 \%$ on student KSAs. The students who are used to traditional classrooms especially for subjects like finance do not feel very comfortable with video lectures and excel sheet models. The students sometimes find online chats not too effective. So their preparedness sometimes takes them to undirected learning.

Table 2. Paired sample t-test of pre-test and post-tests score.

\begin{tabular}{cccccccc}
\hline & & N & $\bar{x}$ & SD & df & t & P \\
\hline Student achievement & Pre-test & 87 & 69.72 & 28.64 & 84 & -3.14 & 0.008 \\
& Post-test & 87 & 77.36 & & & & \\
\hline
\end{tabular}


Table 3. Correlation between student interaction with student achievement, student satisfaction and student KSAs.

\begin{tabular}{ccc}
\hline Model & $\mathbf{R}$ & $\mathbf{R}^{2}$ \\
\hline Student Achievement & $0.170^{\mathrm{a}}$ & 0.028 \\
Student Satisfaction & $0.788^{\mathrm{a}}$ & 0.621 \\
Student KSAs & $0.692^{\mathrm{a}}$ & 0.478 \\
\hline
\end{tabular}

a. Predictors: (Constant), Student Interaction; b. Dependent Variable: Student Achievement; Student Satisfaction; Student KSAs.

The ANOVA test result (Table 4) indicates that the student achievement is not a predictor of student interaction $(\mathrm{F}(1,84)=2.581, \mathrm{p}>0.05)$. thus, student interaction in flipped classroom is not related to higher achievement. Similar to the study, Vinaja et al. [44]), Foon and Sum [45] found there is no correlation between the number of videos viewed and student achievement. This shows that finance when learned by excel spreadsheet exercises, self-practice, watching a video or reading a textbook may not be enough to acquire the KSAs (Adler and Milne [2]). The study thus shows that, students interact in the learning platform by watching the video lecture and completing the pre-class assignment, they would pass the test but not show exceptional grades. The student satisfaction and student KSAs show a difference result with $(\mathrm{F}(1,84)=98.969, \mathrm{p}<0.05)$ and $(\mathrm{F}(1,84)=35.648, \mathrm{p}<0.05)$. Student interaction in a flipped classroom is related to higher satisfaction and KSAs.

\subsection{Difference between Student Engagement on Student Satisfaction, Students KSAs and Student Achievement in Flipped Classroom Environment}

The results show that all the dependent variable is positively associated with student engagement, the highest correlation coefficients, which are the model in a good fit for students KSAs with $\mathrm{R}=0.590$ and student satisfaction, $\mathrm{R}=0.485$ and student achievement are relatively low with $R=0.103$. however there exists weak association between the student engagement and their achievement with only $1.1 \%$. Although, student satisfaction and student KSAs correlations are significant, magnitudes of these correlations are relatively low with $23.5 \%$ and $34.8 \%$ (Table 5).

There seems no significant between the student's achievement and student's engagement in a flipped classroom $(F(1,84)=0.968, p>0.05)$. Thus, student engagement in a flipped classroom does not affect their achievement. Likewise, Siti et al. [46] results also show no correlation between the student engagement and student achievement. Student's high participation in-class may not get higher results although the achievement increases positively. The study states that student engagement in class only through discussion and presentation does not affect their achievement in the test. However, student satisfaction and student KSAs shows contrasting results with the achievement, $(\mathrm{F}(1,84)=39.12, \mathrm{p}<$ 0.05). students with high engagement in-class activities in a flipped classroom has an effect on higher satisfaction and KSAs.( Reeve [42], Adler and Milne [2]) 
show that student engagement will lead to student satisfaction and achievement by adding agentic engagement which includes student's needs in the learning process (Ogunkola, B.J. and R.E. Archer-Bradshaw [47]). The study states that, although student engagement has a significant effect on satisfaction and student KSAs in flipped classroom, the variation of the effect is at a moderate level (Table 6).

Table 4. Significance of student interaction in student achievement, student satisfaction and student KSAs ANOVAa

\begin{tabular}{ccccccc}
\hline Model & & Sum of squares & df & Mean Square & F & Sig. \\
\hline Student Achievement & Regression & 2679.329 & 1 & 2679.329 & 2.581 & $0.092^{\mathrm{b}}$ \\
& Residual & $87,174.243$ & 84 & 1037.788 & & \\
& Total & $89,853.572$ & 85 & & & \\
Student Satisfaction & Regression & 13.163 & 1 & 13.163 & 98.969 & $0.000^{\mathrm{b}}$ \\
& Residual & 11.245 & 84 & 0.133 & & \\
& Total & 24.408 & 85 & & & \\
Student KSAs & Regression & 10.231 & 1 & 10.231 & 35.648 & $0.000^{\mathrm{b}}$ \\
& Residual & 24.123 & 84 & 0.287 & & \\
& Total & 34.354 & 85 & & &
\end{tabular}

a. Dependent Variable: Student achievement; Student Satisfaction; Student KSAs; b. Predictors: (Constant), Student Interaction.

Table 5. Correlation between student engagement with student achievement, student satisfaction and student KSAs.

\begin{tabular}{ccc}
\hline Model & $\mathbf{R}$ & $\mathbf{R}^{2}$ \\
\hline Student Achievement & $0.103^{\mathrm{a}}$ & 0.011 \\
Student Satisfaction & $0.485^{\mathrm{a}}$ & 0.235 \\
Student KSAs & $0.590^{\mathrm{a}}$ & 0.348 \\
\hline
\end{tabular}

a. Predictors: (Constant), Student engagement; b. Dependent Variable: Student Achievement; Student Satisfaction; Student KSAs.

Table 6. Significance of student engagement in student achievement, student satisfaction and student KSAs ANOVA ${ }^{\mathrm{a}}$.

\begin{tabular}{ccccccc}
\hline Model & & Sum of squares & df & Mean Square & F & Sig. \\
\hline Student Achievement & Regression & 778.430 & 1 & 778.430 & 0.968 & $0.092^{\mathrm{b}}$ \\
& Residual & $67,562.842$ & 84 & 804.319 & & \\
& Total & $68,341.272$ & 85 & & & \\
Student Satisfaction & Regression & 7.943 & 1 & 7.943 & 39.128 & $0.000^{\mathrm{b}}$ \\
& Residual & 17.032 & 84 & 0.203 & & \\
Student KSAs & Total & 24.975 & 85 & & & \\
& Regression & 14.212 & 1 & 14.212 & 51.868 & $0.000^{\mathrm{b}}$ \\
& Residual & 23.034 & 84 & 0.274 & & \\
& Total & 37.246 & 85 & & & \\
\hline
\end{tabular}

a. Dependent Variable: Student achievement; Student Satisfaction; Student KSAs; b. Predictors: (Constant), Student Interaction. 


\section{Conclusion and Implications}

The study concludes that students' interactions and engagement in a flipped classroom do not bear any significant correlation as far as achievement, in the finance class valuation topic is concerned in a flipped classroom. There is a significant difference in student interaction and student engagement on student satisfaction and student KSAs toward the topic and have high levels of satisfaction in this study. Students' preparation before class and basic knowledge on the subject matter motivate them to better understanding and learning of finance valuation topic. The course was an elective course for the participants who had opted for this elective under finance major. The pre class material helped create a better mental framework for students towards the subject before coming to the classroom. The main finding of the current study was that there was no significant difference in effectiveness between student interaction and student engagement on student achievement. However, it is effectively significant on student satisfaction and student KSAs. This is a positive result, since students fully engaged in face to face interaction were successful in completing the assignment and tutorial in-class, which means about $0 \%$ of teaching time and $100 \%$ of cost reduction by using free and easy instructional tools. Implementing flipped classroom is not only dependent on the method but involves a change of culture and mind on both good students and lecturers as an instructional designer in higher education specifically to fundamental of finance course at Indian Institute of Foreign Trade IIFT New Delhi, India.

\section{Conflicts of Interest}

The author declares no conflicts of interest regarding the publication of this paper.

\section{References}

[1] Arnold, I. and Hattie, J. (2011) Visible Learning: A Synthesis of over $800 \mathrm{Me}-$ ta-Analyses Relating to Achievement. International Review of Education, 57, 219-221.

[2] Adler, R.W. and Milne, M.J. (2010) Accounting Education: An Improving the Quality of Accounting Students. Learning through Action Oriented Learning Tasks: 37-41.

[3] Hamdan, N., McKnight, P., McKnight, K. and Arfstrom, K.M. (2013) The Flipped Learning Model: A White Paper Based on the Literature Review Titled "A Review of Flipped Learning".

https://flippedlearning.org/wp-content/uploads/2016/07/WhitePaper FlippedLearn ing.pdf

[4] Cynthia, R. and Joseph, E. (2014) Millennial Students and the Flipped Classroom. Proceedings of American Society of Business and Behavioral Sciences, Vol. 21, 519-530.

[5] Strayer, J.F. (2012) How Learning in an Inverted Classroom Influences Cooperation, Innovation and Task Orientation. Learning Environments Research, 15, 171-193. https://doi.org/10.1007/s10984-012-9108-4 
[6] Tucker, B. (2012) The Flipped Classroom. Education Next, 12, 82-83.

[7] Gajjar, N.B. (2013) The Role of Technology in 21st Century Education. International Journal for Research in Education, 2, 23-25.

[8] Sarawagi, N. (2013) Flipping an Introductory Programming Course: Yes You Can! Tutorial Presentation, CCSC: Northeastern Conference.

[9] Mayer, R.E. (2001) Cognitive Theory of Multimedia Learning. In: Mayer, R.E., Ed., Cambridge Handbook of Multimedia Learning, Cambridge University Press, New York, 31-48. https://doi.org/10.1017/CBO9780511816819.004

[10] Heiss, E.D., Obourn, S. and Hoffman, C.W. (1950) Modern Science Teaching. Journal of Chemical Education, 27, 588. https://doi.org/10.1021/ed027p588.2

[11] Bybee, R. (1993) An Instructional Model for Science Education: Developing Biological Literacy. Biological Sciences Curriculum Studies, Colorado Springs.

[12] Lawson, A.E. (2002) Science Teaching and Development of Thinking. Wadsworth/Thompson Learning, Belmont.

[13] Leicht, R.M., Zappe, S.E., Messner, J.I., Litzinger, T. and State, P. (2012) Employing the Classroom Flip to Move Lecture out of the Classroom. Journal of Applications and Practices in Engineering Education, 3, 19-31.

[14] Vygotsky, L.S. (1980) Mind in Society: The Development of Higher Psychological Processes. Harvard University Press, Cambridge. https://doi.org/10.2307/j.ctvjf9vz4

[15] Missildine, K., Fountain, R., Summers, L. and Gosselin, K. (2013) Flipping the Classroom to Improve Student Performance and Satisfaction. Journal of Nursing Education, 52, 597-599. https://doi.org/10.3928/01484834-20130919-03

[16] Means, B., Toyama, Y., Murphy, R., Bakia, M. and Jones, K. (2009) Evaluation of Evidence-Based Practices in Online Learning: A Meta-Analysis and Review of Online Learning Studies.

[17] Clark, R.M., Norman, B.A. and Besterfield-Sacre, M. (2014) Preliminary Experiences with "Flipping" a Facility Layout/Material Handling Course. Proceedings of the 2014 Industrial and Systems Engineering Research Conference, Montreal, 1194-1202.

[18] Lage, M.J., Platt, G.J. and Treglia, M. (2000) Inverting the Classroom: A Gateway to Creating an Inclusive Learning Environment. The Journal of Economic Education, 31, 30-43. https://doi.org/10.1080/00220480009596759

[19] Bergtrom, G. (2009) On Offering a Blended Cell Biology Course. Journal of the Research Center for Educational Technology, 5, 15.

[20] Fulton, K. (2012) Upside Down and Inside Out: Flip Your Classroom to Improve Student Learning. Learning \& Leading with Technology, 39, 12-17.

[21] Johnson, G. (2012) Students, Please Turn to YouTube for Your Assignment. Education Canada, 52, 16.

[22] Tune, J.D., Sturek, M. and Basile, D.P. (2013) Flipped Classroom Model Improves Graduate Student Performance in Cardiovascular, Respiratory, and Renal Physiology. Advances in Physiology Education, 37, 316-320.

https://doi.org/10.1152/advan.00091.2013

[23] Bergtrom, G. (2011) Content vs. Learning: An Old Dichotomy in Science Courses. Journal of Asynchronous Learning Networks, 15, 33-44. https://doi.org/10.24059/olj.v15i1.180

[24] Kazu, I.Y. and Demirkol, M. (2014) Effect of Blended Learning Environment Model on High School Students Academic Achievement. Turkish Online Journal of Edu- 
cational Technology, 13, 78-88.

[25] Keller, J.M. (2010) Motivational Design Research and Development. In: Motivational Design for Learning and Performance, Springer, Boston, 297-323. https://doi.org/10.1007/978-1-4419-1250-3 12

[26] McLaughlin, J.E., Roth, M.T., Glatt, D.M., Gharkholonarehe, N., Davidson, C.A., Griffin, L.M., Mumper, R.J., et al. (2014) The Flipped Classroom: A Course Redesign to Foster Learning and Engagement in a Health Professions School. Academic Medicine, 89, 236-243. https://doi.org/10.1097/ACM.0000000000000086

[27] Siegle, D. (2013) Technology: Differentiating Instruction by Flipping the Classroom. Gifted Child Today, 37, 51-55. https://doi.org/10.1177/1076217513497579

[28] Kim, M.K., Kim, S.M., Khera, O. and Getman, J. (2014) The Experience of Three Flipped Classrooms in an Urban University: An Exploration of Design Principles. Internet and Higher Education, 22, 37-50. https://doi.org/10.1016/j.iheduc.2014.04.003

[29] Siti, Z.M.O., Rozinah, J. and Nur, E.M. (2014) Flipped Classroom and Traditional Classroom: Lecturer and Student Perceptions between Two Learning Cultures, a Case Study at Malaysian Polytechnic. International Education Research, 2, 16-25. https://doi.org/10.12735/ier.v2i4p16

[30] Ryan, R.M. and Deci, E.L. (2000) Self-Determination Theory and the Facilitation of Intrinsic Motivation, Social Development, and Well-Being. American Psychologist, 55, 68-78. https://doi.org/10.1037//0003-066X.55.1.68

[31] Flumerfelt, S. and Green, G. (2013) Using Lean in the Flipped Classroom for at Risk Students. Educational Technology \& Society, 16, 356-366.

[32] Davies, R.S., Dean, D.L. and Ball, N. (2013) Flipping the Classroom and Instructional Technology Integration in a College-Level Information Systems Spreadsheet Course. Educational Technology Research and Development, 61, 563-580. http://www.flippedlearning.org/definition https://doi.org/10.1007/s11423-013-9305-6

[33] Gagne, R., Briggs, L. and Wager, W. (1992) Principles of Instructional Design. 4th Edition, HBJ College Publishers, Fort Worth.

[34] Pierce, R. and Fox, J. (2012) Vodcasts and Active-Learning Exercises in a Flipped Classroom Model of a Renal Pharmacotherapy Module. American Journal of Pharmaceutical Education, 76, 196. https://doi.org/10.5688/ajpe7610196

[35] Creswell, J.W. (2012) Educational Research: Planning, Conducting, and Evaluating Quantitative and Qualitative Research. 4th Edition, Pearson Education, Upper Saddle River.

[36] Murray, D., Koziniec, T. and Mcgill, T. (2013) Student Perceptions of Flipped Learning. International Journal of an Emerging Transdiscipline, 16, 99-115.

[37] Jonassen, D. (1998) Designing Constructivist Learning Environments. In: Reigeluth, C.M., Ed., Instructional Theories and Models, 2nd Edition, Lawrence, Mahwah, 215-239.

[38] Chen, Y., Wang, Y. and Chen, N.S. (2014) Is FLIP Enough? Or Should We Use the Flipped Model Instead? Computers \& Education, 79, 16-27.

https://doi.org/10.1016/j.compedu.2014.07.004

[39] Wilson, S.G. (2013) The Flipped Class: A Method to Address the Challenges of an Undergraduate Statistics Course. Teaching of Psychology, 40, 193-199. https://doi.org/10.1177/0098628313487461

[40] Roach, T. (2014) Student Perceptions toward Flipped Learning: New Methods to 
Increase Interaction and Active Learning in Economics. International Review of Economics Education, 17, 74-84. https://doi.org/10.1016/j.iree.2014.08.003

[41] Kuo, Y., Walker, A.E., Schroder, K.E.E. and Belland, B.R. (2014) Internet and Higher Education Interaction, Internet Self-Efficacy, and Self-Regulated Learning as Predictors of Student Satisfaction in Online Education Courses. Internet and Higher Education, 20, 35-50. https://doi.org/10.1016/j.iheduc.2013.10.001

[42] Reeve, J. (2013) How Students Create Motivationally Supportive Learning Environments for Themselves: The Concept of Agentic Engagement. Journal of Educational Psychology, 105, 579-595. https://doi.org/10.1037/a0032690

[43] Crews, T. and Butterfield, J.B. (2014) Data for Flipped Classroom Design: Using Student Feedback to Identify the Best Components from Online and Face-to-Face Classes. Higher Education Studies, 4, 38-47. https://doi.org/10.5539/hes.v4n3p38

[44] Vinaja, R., Texas, A. and Antonio, M.U. (2014) The Use of Lecture Videos, Ebooks, and Clickers in Computer Courses. Journal of Circuits, Systems, and Computers, 30, 23-32.

[45] Foon, K. and Sum, W. (2014) Students and Instructors Use of Massive Open Online Courses (MOOCs): Motivations and Challenges. Educational Research Review, 12, 45-58. https://doi.org/10.1016/j.edurev.2014.05.001

[46] Siti, Z.M.O., Rozinah, J. and Nur, E.M. (2014) Student Engagement and Achievement in Active Learning Environment among Malaysian Polytechnic Commerce Department. Journal of Education and Literature, 2, 8-17.

[47] Ogunkola, B.J. and Archer-Bradshaw, R.E. (2013) Teacher Quality Indicators as Predictors of Instructional Assessment Practices in Science Classrooms in Secondary Schools in Barbados. Research in Science Education, 43, 3-31. https://doi.org/10.1007/s11165-011-9242-5 